\title{
Environmental Education As a Cultural Basis for the Management of Solid Waste: Yucatan Case Study
}

\author{
Alejandra Edith Salazar Euan, Mayanín Asunción Sosa Alcaraz, and Guadalupe Valladares Gamboa
}

\begin{abstract}
Because natural limits and economic growth are being exceeded today, the world cares for the environment. The current economic rationale focuses on maximizing production and seeking the accumulation of wealth, which has devastating consequences for society and the natural environment. Therefore, it is very important to know the current state of the environment, the regulations for production and consumption, and the management of urban and rural waste. Education is the ideal way to address the various environmental and social problems that modern society experiences. Different strategies and actions in education can be carried out so that children, youth and adults act towards the environment with responsibility and awareness. In fact, various governments have already implemented public programs on environmental education in communities and schools. For this reason, this article aims to present information and reflections about the problem and excessive generation of solid waste, the role that education and environmental culture play in its management, and how it can be used to try to alleviate this problematic. This was achieved using a documentary and literature analysis. This analysis shows the need to reinforce learning oriented to the development of skills and perceptions in the face of real-world environmental problems, applying a multidisciplinary approach and trusting on the participation of rural communities.
\end{abstract}

Index Terms-ecological education, environmental culture, solid waste, environment, yucatan

\section{INTRODUCTION}

The production and consumption of goods and services inevitably generate some type of waste. This can be solid (organic or inorganic), liquid (those that are discharged dissolved as wastewater) and those that escape in the form of gases. The generation and management of waste implies social and environmental impacts, as well as those impacts on public health. Furthermore, the irrational and excessive use of natural resources, as well as the excessive and uncontrollable generation of solid waste resulting from their transformation, represents one of the most important and serious environmental problems today (Conesa, 1997). As Downs and Acevedo (2019) mention that people around the world are generating a lot of trash, and there is no an appropriate way to deal with it. Sometimes, waste is not biodegradable and damages our oceans and soil. For example, in 2017 , the total generation of municipal solid waste in the United States was 267.8 millions tons. This means an increase of 5.7 million compared with 2015. These authors say that the externalities of waste is affecting the environment such as climate crisis and ecological health.

Published on February 13, 2021

Alejandra Edith Salazar Euan, Tecnológico Nacional de México Campus Instituto Tecnológico de Mérida, México.

(edidth_15@hotmail.com)

Mayanín Asunción Sosa Alcaraz, Tecnológico Nacional de México Campus Instituto Tecnológico de Mérida, México.

(mayanin.sa@ merida.tecnm.mx)
In Mexico, solid waste management is a big problem of great economic, social, environmental, and health impact. Around 30.1 millions tons of garbage per year is generated in the country (INEGI, 2017). Since the insufficiency of economic and human resources, the deficit of necessary infrastructure, the lack of education on environmental culture, generates a lack of comprehensive solutions, absence of environmental training programs, as well as incipient technology, among many other factors (Jaramillo, 1999).

Fortunately, various actions and strategies related to the issue of waste generation have already been implemented in Mexico and other parts of the world. For instance, the Arizona Association for environmental education (n.d.) offers a certification program, where participants are part of an environmentally literate citizenry network of high quality. In addition, there is a manifesto for environmental education in Europe that is supported by more than 150 actors from different countries to show their interest to educate towards environment and sustainable development (Manifesto Europe, 2014). This manifesto presents twenty proposals to address this priority issue. In America, Eco Canada (2020) is a steward for the Canadian environmental workforce across all industries. This organization supplies human resources to public and private sector with the skills and knowledge related to environment. It has online courses, webinars, and indigenous training in order to contribute towards the achievement of sustainability. In fact, it can be seen environmental education material from diverse websites, where a person can find resources to understand the process of supply and recycling.

In Yucatán, there is a special management program for urban and special solid waste. The Secretariat of Sustainable Development offers an environmental education and culture activities, and workshops to cleaning personnel and for the authorities involved in the rural municipalities of the state, to achieve the correct integral management of solid waste, from collection to final disposal sites (Secretaría de Desarrollo Sustentable, 2020a). However, it has not been enough how the local government has approached these programs to rural communities. There is a lack of resources on education and information related to solid waste and environment. In this way, the importance of having an effective education system for the conservation of nature and ecosystems is needed and urgent, especially in Yucatan, Mexico. More relevant is how this type of education can help to not only practice recycling and waste reduction, but also change behavior and attitude of people towards environment care.

The present article aims to analyze reflectively how the education and environmental culture in Yucatan can play a

Guadalupe Valladares Gamboa, Tecnológico Nacional de México Campus Instituto Tecnológico de Mérida, México.

(guadalupe.vg@ merida.tecnm.mx) 
preponderant role in the face of waste generation and use challenge. The purpose is to present a literature analysis as part of a broader research on the environmental problem generated by the lack of ecological education, natural and social values, specifically on how society can reduce and manage urban solid waste, and how environmental education can contribute to the public awareness. The result of such research will be to plan and implement diverse activities of ecological education and environmental culture in rural communities of Yucatan in a second phase.

\section{URBAN SOLID WASTE: TYPES, CLASSIFICATION AND MANAGEMENT.}

Urban solid waste (USW) is the waste material that is produced at homes and at those establishments that the General Mexican Law for the Prevention and Integral Management of Waste does not consider as large generators. They can also be:

1) Organic: Any waste of biological origin that was once alive or was part of a living being.

2) Inorganic: Any waste that is not of biological origin.

3) Special handling waste: It is used to refer to solid waste generated in large volumes. Special handling wastes are those that come from health institutions, with the exception of biological infectious.

In this sense, the management of the integral waste is the set of activities necessary for the treatment of waste, from its generation to its elimination or reuse, which includes the collection, transport, the management of those that are especially dangerous, and the recycling of usable materials. Likewise, the integral management of urban solid waste (USW), based on sustainable development, has as its primary objective the reduction of waste sent to final disposal, which translates into a decrease in the extraction of natural resources, energy source and water used for the production process (Ley General para la Prevencion y Gestion Integral de los Residuos, 2003).

Globally, 37 percent of waste is currently dumped or disposed of in some form of a landfill, of which 8 percent is taken to generate and collect gas. Open dumping accounts for about 31 percent of waste, 19 percent is recovered through recycling and composting, and 11 percent is incinerated for final disposal. Adequate waste disposal or treatment, such as controlled landfills or more stringently operated facilities, is almost exclusively the domain of high- and upper-middleincome countries. Lower-income countries generally rely on open dumping; 93 percent of waste is dumped in low-income countries and only 2 percent in high-income countries (World Bank, 2020). In this sense, in most countries, solid waste management operations are typically a local responsibility, and nearly 70 percent of countries have established institutions with responsibility for policy development and regulatory oversight in the waste sector. About two-thirds of countries have created targeted legislation and regulations for solid waste management, though enforcement varies drastically.

In Mexico, rapid urbanization tests the provision of public services due to the constant growth of the population, budgetary pressures and complex organization schemes. For this reason, the study of the integral management of urban solid waste works as an input from a systemic approach, to analyze the determinants, actions, and arrangements involving diverse actors who can solve a public problem and support social innovation proposals. This is complicated when the management of USW is carried out at the municipal level. At this level, it is impossible to have the financial, legal, physical and technical infrastructure necessary for their proper management. For this reason, the traditional management of USW in Mexico is not optimal and requires a prompt incorporation of priority activities such as waste minimization and recycling (Calvo and Aguilar, 2008).

All of the above has led to the emergence of initiatives and programs in Mexico for the preparation, execution and evaluation of solid waste; as well as, the execution of programs for the protection, restoration and improvement of the environment; for the preservation and protection of biodiversity, and the prevention and control of environmental risks. An example of this is the coordination of environmental policies and culture office in Mexico City, which is in charge of priority environmental management programs. In fact, the environmental education centers were created to make the population aware of the care of environmental services and the culture of recycling (Secretaría del Medio Ambiente, 2020).

In Yucatán, according to statistics from the Secretariat of Sustainable Development (2020), about 2,016 tons of garbage are produced daily, of which more than $50 \%$ are deposited in sanitary landfills in the capital municipality; while the remainder is deposited in open-air landfills in the remaining municipalities. This institution also reported that only about 1,487 tons are collected, which represents approximately $73 \%$ of total coverage. Likewise, of the total waste generated daily, only 178.5 tons are collected separately (organic and inorganic), this is, only $8.82 \%$ of the USW generated daily in Yucatan, are separated and collected properly.

The foregoing was one of the reasons for the creation of the General Law for the Prevention and Integral Waste Management in Yucatán, on April 8, 2011. Subsequently, its implementing regulations on August 6, 2012, both having as main objective to guarantee the right of people to a healthy environment and to promote sustainable development through the prevention of generation, recovery, and integral management of hazardous, solid and special waste (Decree 396, 2011; Decree 539, 2012).

As a result, Yucatan has encouraged a high promotion of a program called "Zero Waste", which seeks to make use of waste, through an environmental culture and infrastructure to improve management and reduce negative effects on the environment. Because of this regulatory framework, the Secretariat of Sustainable Development developed a program called "Integral Management of Waste" for environmental education and culture. This program offers training and advice aimed at rural authorities for the integral management of solid waste, from collection to final disposal sites, sanitation of rural garbage dumps and their rehabilitation; however, it much remains to do (Secretaría de Desarrollo Sustentable, 2020a). The president of the College of Graduate Studies in Environmental Sciences believes that Yucatan is suffering an environmental crisis. This mainly due to the poor handling of garbage and water pollution. All rural municipalities in Yucatan have open-air garbage dumps and many families still burn the garbage, although it is prohibited. The serious problem of pollution caused by waste and residues, both globally and locally, is probably related to the lack of culture, awareness, and environmental education. 
For this situation, the Government of Yucatán has implemented a Medium-Term Sector Program called "Green and Sustainable Yucatán", in which actions and strategies are proposed based on the identification of problems and the collection of information. One of the strategic themes is the integral management of solid and special waste in rural municipalities. Another strategy is to increase the "culture for sustainability", because some weaknesses were highlighted such as: a) the lack of formal environmental education workshops, b) the insufficient activities in education and environmental culture in the urban and rural municipalities, and c) the low coverage of environmental dissemination campaigns within the state (Secretaría de Desarrollo Sustentable, 2020b).

In this sense, the proper handling and management of urban solid waste should favor and encourage the recycling and use of recovered materials as a source of energy or raw materials, in order to contribute to the preservation and rational use of natural resources. In fact, recycling may be carried out in two ways: the first consists of the components separation present in the garbage from the main source, for their direct recovery, this is known as selective collection. For this system to be effective, citizen participation is needed, as they have to carry out the work of separation at the main source. The second way is starting from the gross garbage, performing its classification using techniques such as crushing, screening and pneumatic classification for the preparation of the waste and separation of the light fractions (López, 2009).

The recycling of some wastes has been considered as the most viable alternative for their management and use (Lund, 1997). One of the main beneficial impacts of the proper management of solid waste is the recovery of materials, which in addition to contributing to solving the waste problem, has the potential to create civic awareness. From the social point of view, separation at the source has several advantages, such as the development of citizen participation in community problems, the awareness of the community itself on environmental and health problems, as well as the transition to a new society with environmental education and culture (Quiroz, 2009).

\section{THE IMPORTANCE OF ENVIRONMENTAL EDUCATION AND CULTURE IN THE MANAGEMENT OF URBAN SOLID WASTE.}

Education is understood as a process of continuous sociocultural development of the capacities that people must generate and that is carried out both inside and outside their environment, throughout their lives. Education involves boosting skills and cognitive structures, which allow sensory input and perception of the real world. In addition, it contributes values and customs, which determine our behaviors or ways of acting (Alvarez, 2003).

In this context, the concept of "Environmental Education" was used for the first time in 1972, in Stockholm, during the International Conference on the Environment. Since then, it has been granted the preponderance to generate changes, through the acquisition of knowledge, attitudes and values that allow us to seriously face the world's environmental crisis with a view to achieving a better quality of life for current and future generations. In this way, for many authors, environmental education is the basic tool for all people to become aware of the importance of preserving their environment and be able to make changes in their values, behavior and lifestyles, as well as expand their knowledge to propel them to action by preventing and mitigating existing and future problems (Gomera, 2008). Environmental culture establishes the parameters of relationship and social reproduction in relation to nature. Bayón (2006) mentions that this must be based on the relationship of man with his environment, and in this relationship is implicit the set of styles, customs and living conditions of a society with its own identity, traditions, values and knowledge. Likewise, Roque (2003, p.10) says that "culture is a heritage and a component of the environment; therefore, its conservation is a sovereign right of each people".

All the characteristics of a culture are influenced by the natural environment in which society develops; this environment has a great influence on the character of cultural identity of the peoples. Hence, each civilization leaves its mark on its natural resources and on its society, and the results of this transformation process determine the state of its environment. "When the system of material and spiritual values is built from the rational use of natural resources, based solely on real needs, society is oriented towards sustainable development" (Roque, 2003, p. 10). Similarly, the creation of cultural value through education, achieves greater environmental awareness in society, which can lead to new forms of organizations that seek more than a simple economic benefit, such as the company Triciclos.

The Triciclos company is an organization that was born in Chile, and may be defined as a company of cultural change towards sustainability, where recycling represents a means to create transversal value, generating important social and environmental benefits. This innovative organization aims to achieve zero waste in the industry, and not simply to maximize economic profit. The company created an innovative strategy: to subsidize the collection, processing and recycling a large part of waste, which had not been paid attention because it did not generate significant rates of financial return. But, this waste went on to swell the indexes of tons of garbage that flooded throughout the country, for not being one of the main materials demanded by industries as raw material. Subsequently, waste reception points were created, and through the training of people who were dedicated to informal waste collection, it was possible to form a brigade of facilitators who guided and acted as environmental and filter trainers to avoid leaving what was left behind, neither cannot be recycled or the waste already classified is contaminated (Gatica, 2013).

This formula achieved through a cross-subsidy, the profits that were generated through the processing of the main recycled materials that the industry demanded, could be processed the least demanded materials, and most of the times, their processing presented economic losses. This allowed them to be able to cover about $90 \%$ of disposable solids that are technically recyclable, in contrast to the $14 \%$ that is currently covered, through the collection of only the three most profitable materials. Finally, through a crosssubsidy, favorable economic results and notable environmental results were achieved. The installation of reception points that were attended by people who previously engaged in informal collection and recycling, improved their economic income, obtained access to social security, accessed a job "socially" more acceptable and, in general terms, have access to a better quality of life. 


\section{MATERIAL AND METHODS}

For this first part of the research, a review of the literature and documentary analysis on the importance of environmental education in the management of urban solid waste was developed. In particular, the state of Yucatan as a case study. A systematic, technical and analytical review of scientific articles, government webpages, research journals, books published by experts on the subject were carried out to collect relevant information on the current situation of the regional problem regarding the excessive and uncontrolled generation of solid waste, and the bad management of this.

For a literature review or document to be considered, a comparative and analytical technique is required, relevant information was synthesized and compared that allowed to establish the necessary bases to achieve a correct assimilation of existing information and available knowledge, to subsequently convey a discussion and create reflections on the subject (Cortés and León, 2004). The idea was to examine similarities, examples and outcomes of diverse source of information on waste management related to environmental culture. As well as to identify some characteristics of environmental programs and regulations in order to reflect if, education can help to change attitudes and the way of waste management.

Yucatan it is located in the southeast of the Mexican Republic, in the northern part of the Yucatan Peninsula. It is bordered to the north and west by the Gulf of Mexico, to the southeast by the state of Quintana Roo, and to the southwest by the state of Campeche. Its territorial extension is 39,524 $\mathrm{km} 2$ (2.02\% national totality extension). It is made up of 106 municipalities, and its capital city is Merida. The state has 2 097175 inhabitants (1.8\% national totality) and the main activity is commerce (INEGI, n.d).

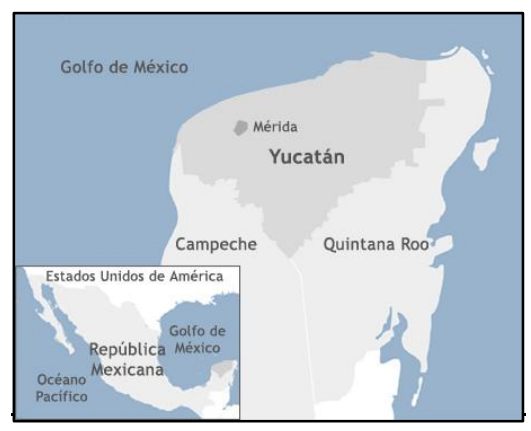

Fig. 1. Yucatan geographic location

\section{ANALYSIS AND REFLECTION ON ENVIRONMENTAL EDUCATION REGARDING WASTE MANAGEMENT IN YUCATAN}

Within the environmental problem, the irrational and excessive use of natural resources, as well as the excessive and uncontrollable generation of solid waste resulting from the transformation of such natural resources, represents one of the most important and serious environmental problems today. In fact, worldwide concern about this situation is increasing, so we constantly work on finding solutions to achieve solid waste management with a low environmental impact, always considering the economic, social and environmental dimensions (Conesa, 1997). In the same way, the integral management of this type of waste must consider important changes on ecological education, such as how society manages and disposes the solid waste.
In Mexico a single person produces almost one kilo of solid waste per day, which results in the generation of just over 42 million tons per year (SEMARNAT, n.d.). The biggest problem of this situation is that many of this waste that go to landfills are materials that can be recovered and recycled. For this reason, it is important to understand that recycling helps to make efficient use of natural resources, since it complements or replaces a considerable part of the raw materials that are extracted directly from nature by human demand. Consequently, it is necessary to change consumption habits by educating people in favor of the environmental conservation. Responsibility on consuming does not necessarily imply "not consuming", rather it means being aware of what it is consumed, the final destination of the products, and how the type of waste impact our environment.

The Mexican Ministry of Public Education (SEP) works to reinforce environmental education at all levels of education as a pillar of human well-being and sustainability. This ministry builds study plans and programs to convey a message on the protection of the environment. For this reason, in 2020 a discussion was held to inform teachers, professors, and specialists in environmental protection content. Diverse actions and projects are necessary to lead into an extremely complex process of curricular change, not only because many new parameters have to be handled, as Morín (2000) warns, this change implies a process of understanding and analysis phenomena, as well as their root causes.

In spite of the Integral Management of Waste Law of Yucatán, and its regulation as a guarantee of a healthy environment for people, it is not only enough to have a good initiative, but to take into account other important aspects such as the cultural bases and ecological education of each rural municipality within the state. Since, we have a vast interculturality, which requires constant monitoring and evaluation of different kind of strategies for the fulfillment of the sustainable development objectives (Decree 396, 2011; Decree 539, 2012). Some programs that are currently outdated and were part of the strategies of the predecessor government (2012-2018), are related to caring for the environmental education. These strategies sought to raise awareness and mitigate the problems caused by the excessive generation of USW (Secretaría de Desarrollo Sustentable, 2020b).

1) Recycle for your well-being. Promoted the culture of recycling to contribute to the fight against dengue illness and improve the quality of life.

2) Educational Program for the Promotion of an Environmental Culture as a Way of Life (Sustainable School). Strengthening of the environmental culture through the delivery of environmental education workshops, accompaniment to the processes and certification of responsible schools.

3) Environmental Education Program of the "Yumtsil" Park. Contributed to the reduction of environmental degradation and avoided the loss of Mayan cultural heritage through the application of educational strategies that allow the generation of significant learning in the population to promote responsible actions that contribute to the conservation of the cultural and environmental heritage of the Yucatan state.

Currently, the Secretariat of Sustainable Development of Yucatán proposes an educational program for the promotion 
of an environmental culture as a way of life (sustainable schools) in order to have educational communities being aware of the value of the natural resources. This program aims to be at educational centers from basic to higher levels, as a tool for the teaching of environmental issues, as well as awareness and reflection on the care of the natural environment. This means to be aware of the ecological reality, and the urgent need to take critical positions and influence decision-making process. By the identification of the problems and potentialities of the Yucatan region to promote spaces in which values such as the sense of belonging, responsibility, tolerance, as well as positive attitudes towards the conservation of the environment should be encouraged (Hernández and Tilbury, 2006).

Another med-term program for 2018-2024 includes a section on the integral management of solid and special waste, under the framework of the "Towards a Zero Waste Yucatán" strategy. Various actions are being implemented for the maximum use and integral management of solid waste, through the promotion of an environmental culture, equipment and innovative infrastructure (Secretaría de Desarrollo Sustentable, 2020b). This opens the door for the analysis of waste generation and composition that varies according to the type of economy and culture of every region. This has repercussions on the way of how solid waste management is achieved, a matter that has also been addressed in other studies. In fact, the economic, technological, educational, social and cultural gap among countries of the "first" and "third" world marks an important contrast in how waste management is managed in each territory. In industrialized countries, waste management results in effective maneuvers by having the relevant legal frameworks, education and culture necessary to comply with environmental regulations (Kathiravale and Muhd, 2008).

In this context, education, and especially environmental education, contributes to generating in society a critical, reflective and comprehensive awareness of our situation on the planet. It is also an important agent in the transition to a new ecological phase of humanity, as it lays the foundations to understand the relationship between human beings and the environment. Opening the possibility of creating an environment where the relationship between man and nature is of respect and gratitude, containing people capable of interpreting and transforming the world and giving equal importance to the rights of all living beings (Freire, 1995).

Education allows the construction, reconstruction and reflection of knowledge, value behaviors and the development of individual and collective capacities. Environmental education offers a broader approach that encourages critical, reflective and innovative thoughts, which allow creating an opinion about socio-environmental problems. Gonzalez (2003) says that environmental education reinforces the commitment to contribute to social, cultural and economic change, based on the development of values, attitudes and skills allowing everyone to form a criteria, assume a responsibility and play a constructive role in caring for and conservation of the environment.

Similarly, environmental culture reflects man's relationship with his environment, determining the degree of conservation. In contrast, globalization generates unsustainable lifestyles because it is based on the existence of a development model that is uneven for human societies and that is harmful to natural systems. Development generates greater production of waste that requires higher levels of handling and delivery of products, which become negative and invasive elements for the environment and affecting human life (Miranda, 2013).

In Europe, some ecological education and environmental culture proposals are: (a) integrate the ecological and environmental education into school's curriculums, transversely and across the others disciplines. This form sensitized teachers to ecological issue and able to raise with students the complex problems of today, such as socially and environmental issues. This generate more environmental and ecological culture in society; (b) also, encourage the ecological education in society with non-formal education, giving particular attention to the most disadvantaged, in particular in rural communities, by supporting the monitoring of participatory initiatives of eco-citizenship. Also, (c) integrate ecological topics in all the courses of higher education, integrating environmental and sustainable development contents in all university careers. In the laboral world, (d) encourage and ecological practices in the diary activities. Finally, (e) the Governments of Europe Union implement a transversal program of ecological education and environmental culture at statewide, also to integrate the Sustainable Development Goals (SDG's) in the actually and next development plans (Manifesto Europe, 2014).

The creation of innovative companies that give the same importance to the social and environmental sphere, as they do the economic domain, is a way of tackling the socioenvironmental problems that currently exist. With the analysis of the TriCiclos case, it is possible to understand the importance of environmental education as a generator of a new culture. Generating a change of mentality, and reasoning about the consumption habits and uncontrolled generation of solid waste that exists today. Then, knowing the true origin of the product materials, which some of these are not recyclable and there is no process plant to reuse them, it will germinate a change seed towards a society that is more aware of the problem and begins to take action on the problem (Miranda, 2013). In this sense, awareness, through education and environmental culture, is capable of generating a domino effect that ends up producing changes that force industries to evolve towards more sustainable industries. For this reason, it is important to understand the importance of education and environmental culture to deal with various environmental problems.

It is then needed to demand changes in the current Mexican education system, preparing students with a global vision of the preservation of natural ecosystems, recognizing the solidarity and synergies among diverse global and regional actors to face global/local environmental problems due to our economic system. Vigotsky (1978) believes that man and his mind are the result of culture and education; the mind, values, affections, emotions, character, knowledge, cognition, and the particularities of the body are part of culture and education. Just as the body of the fisherman is different from the body of the farmer, and the body of Chinese sportsmen is different from the body of Chinese musicians or poets, the personality is the result of culture and education. For this reason, it is important to understand the importance of education and environmental culture to try to alleviate the problem of solid waste, as well as many other environmental problems. The different academic disciplines need to work together towards the same goal, which is to achieve high levels of awareness about the current system of production 
and distribution of products, which leads to the generation of unwanted waste for the environment.

The improvement of the educational curriculum in Yucatan implies: a) aligning the holistic formation of the student with the sustainable development of the region, and b) promoting an organizational transformation that supports the learning, research and service processes. It is vital to have a strategy that promotes a synergy that integrates the institution, the student and the companies, to face new challenges arising from the expansion of the knowledge society and economy. In this way, diverse educational efforts would add to assume the role of a regional development active agent. Training professionals in accordance with the needs of sustainability, and generating projects that promote healthy and sustainable communities.

However, not only education curriculum system needs to be addressed, but also the rural communities, where adult and young people are facing environmental problems. Every member in the community has the same responsibility to overcome these problems. People have to know that the natural damage and its solution is now, the present, not just the future. It is not just about regulations, rather an encouragement of how society view the environment is relevant. A lifestyle and consumption change is more crucial than ever. Hence, a system change study should be approached, because this would produce certain behavioural skills and rules in relation to the environment, and develops optimization and harmony between humans and nature (West, 2015). In addition, it is essential to reinforce empowerment and student-centered learning oriented to the development of skills and perceptions of self-efficacy in the face of real-world environmental problems, through a multidisciplinary approach that leads them to identify and deliberate appropriate courses of action, always relying on the important social participation of rural communities (Stern, Powell and Hill, 2013).

For instance, some ecological education and environmental culture systemic change in rural communities of Yucatan would be: a) capacity building, b) teamwork, c) pedagogy/literacy, d) policies, and e) shared-competencies. Maybe, these do not work for every community, but it is critical to find the right drivers that allow each rural community to control and reduce their solid waste, influencing in a positive way of doing things differently and working towards a circular economy. This means a regenerative and restorative economic model for this region.

In this context, developing a didactic and interdisciplinary model where the approaches (systemic, community and interdisciplinary) of Environmental Education are interrelated allows a greater inclusion of environmental issues in school curricula, from basic education to higher education, which would generate changes significant in the Yucatan educational system, resulting in greater awareness and environmental culture. In the same way, it is necessary to encourage in teachers, students and the community a thought that allows them to approach the reality in which they currently live.

As an educational strategy, it is important to create pedagogical projects with the objective of allowing students, teachers and educational institutions to align their school dynamics towards solving real problems in Yucatan, through social entrepreneurship and the rational use of existing natural resources in the environment, all this as a basis for collaborative learning and social development.
The foregoing opens the door for the creation of a nonformal educational training program of an applicative nature directly in the rural communities of Yucatan, which would have the objective of promoting community organization with respect to sustainable development in order to change the attitudes of the communities. people who live in situations of environmental deterioration, for the generation of an educational proposal to improve the relationship between human beings and the environment.

\section{CONCLUSIONS}

The production and consumerism patterns and the way of life of the people have led to an exponential increase in solid waste generation causing serious environmental problems. Considering that waste is an indissoluble result of one's life and the development of human activities, it has been necessary to seek a solution to the problem associated with them, where the contribution of education and environmental culture aims to promote participatory capacity and create social behaviors that minimize the environmental impact of our activities, trying to integrate pollution prevention into the daily activities of social life.

In this sense, after the document, analysis the ecological education could be the way to go, because perceives environment as a global and systemic manner, in its temporal and spatial dimensions regarding the totality of daily problems, especially concerning water, mobility, consumption, supply, waste, habitat, energy, climate, biodiversity and health. As well, there is a need to attend the development of environmental attitudes and social abilities to reinforce environmental culture across society in order to boost a sustainability model, particularly in Yucatan.

Finally, the proposals mentioned in this study, aim to generate awareness, information, training and participation in collective actions; it addresses everyone, everywhere, with formal and informal education, from young children to adults; in schools, universities, enterprises, communities, government. This addresses to responsible men and women, who wish a real shift for environmental system.

\section{REFERENCES}

Alvarez, A. (2003). Factores de Éxito para el Desarrollo de Estrategias Nacionales de Educación Ambiental. Congreso Iberoamericano de Educación Ambiental. Fundación Polar. Caracas, Venezuela.

Arizona Association for Environmental Education. (n.d.). The arizona environmental education certification program. Retrieved from https://www.arizonaee.org/arizona-environmental-educationcertification-program/

Bayón, P. (2006). Educación Ambiental, participación y transformación social sostenible en Cuba. Revista Interface, 2(4), 89-104. Recuperado de http://biblioteca.filosofia.cu/php/ export.php? format $=$ htm\&id $=2335 \&$ view $=1$

Calvo, A. \& Aguilar, M. (2008). El comportamiento ecológico responsable: un análisis desde los valores biosféricos, sociales altruistas y egoístas. Revista Electrónica de Investigación y Docencia, 11(25).

Conesa, V. (1997). Guía metodológica para la evaluación del impacto ambiental, (2a ed.). Madrid: Editorial Mundi-Prensa

Cortés, M., \& León, M. (2004). Generalidades sobre metodología de la investigación. Ciudad del Carmen, Campeche. México D.F.: Universidad Autónoma Del Carmen

Decreto 396. (8 de abril de 2011). Ley para la Gestión Integral de los Residuos en el Estado de Yucatán. Boletín del Gobierno del Estado de Yucatán. Recuperado de http://tjay.org.mx/?wpfb_dl=32

Decreto 539. (6 de agosto de 2012). Reglamento De La Ley Para La Gestión Integral De Los Residuos En El Estado De Yucatán. Boletín del Gobierno del Estado de Yucatán. Recuperado de 
http://legismex.mty.itesm.mx/estados/ley-yuc/YUC-RGesIntRes2012_08.pdf

Downs, A. \& Acevedo, R. (2019). How our trash impacts the environment. EarthDay. Retrieved from https://www.earthday.org/how-our-trashimpacts-the-environment/

Eco Canada. (2020). Environmental Educator. Retrieved from https://www.eco.ca/training/career-profiles/environmental-educator/

Freire, P. (1995). La educación como una acción cultural. San José, Costa Rica: EUNED.

Gatica, S. (2013). Cómo hacer sustentable la sustentabilidad: el caso de Triciclos. FOMIN

González, G. (2003). En pos de la historia en educación ambiental. Revista Tópicos de Educación ambiental, 3(8), 28-43.

Gomera, A. (2008). La conciencia ambiental como herramienta para la Educación Ambiental: conclusiones y reflexiones de un estudio en el ámbito universitario. Córdoba: SEPA.

Hernández, M. y Tilbury, D. (2006). Educación para el desarrollo sostenible, ¿nada nuevo bajo el sol?: consideraciones sobre cultura y sostenibilidad Revista Iberoamericana de Educación. Recuperado de https://www.researchgate.net/publication/28132159_Educacion_para_el _desarrollo_sostenible_nada_nuevo_bajo_el_sol_consideraciones_sobre _cultura_y_sostenibilidad

Instituto Nacional de Estadística y Geografía [INEGI]. (n.d.). Cuentame; Información por Entidad. INEGI. Retrieved from http://www.cuentame.inegi.org.mx/monografias/informacion/yuc/defaul t.aspx ?tema $=$ me $\&$ e $=31$

Instituto Nacional de Estadística y Geografía [INEGI]. (2017). Censo Nacional de Gobiernos Municipales y Delegacionales 2017., Módulo 6: Residuos Sólidos Urbanos. INEGI. Retrieved from https://inegi.org.mx/rnm/index.php/catalog/535

Jaramillo, J. (1999). Gestión integral de residuos sólidos municipalesGIRSM. Seminario Internacional Gestión Integral de Residuos Sólidos y Peligrosos.

Kathiravale, S. y Muhd, Y. (2008). Desperdicio a la riqueza. Revista Asia Europa, 6(2), 359-371. Recuperado de https://www.researchgate.net/publication/5143582_Waste_to_wealth

Ley General para la Prevención y Gestión Integral de los Residuos. (8 de octubre de 2003). Diario Oficial de la Federación. Recuperado de http://www.diputados.gob.mx/LeyesBiblio/pdf/263_190118.pdf

López, N. (2009). Propuesta de un programa para el manejo de los residuos sólidos en la plaza de mercado de Cerete en el departamento de Córdoba. Universidad Pontificia Javeriana, p. 151

Lund, H. (1997). Manual del reciclaje. México, DF. Editorial Mc Graw Hill

Manifesto for Environmental Education and Sustainable Development Europe (2014). Educate towards environment and sustainable development. EESD. Retrieved from http://www.for-eesd-in europe.org/sites/default/files/manifeste\%20EEDD\%20-\%20English.pdf

Miranda, L. (2013). Cultura ambiental: Un estudio desde las dimensiones de valor, creencias, actitudes y comportamientos ambientales. Revista Producción + Limpieza, 8(2), 94-105. Recuperado de http://repository.lasallista.edu.co:8080/ojs/index.php/pl/article/view/527/ 276

Morín, E. (2000). La mente bien ordenada. Repensar la reforma. Reformar el pensamiento. Barcelona: Seix Barral. Los tres mundos.

Quiroz, J. (2009). Concreto reciclado: una revisión. Revista ALCONPAT, 5(3), 235-248. Recuperado de https://www.redalyc.org/pdf/4276/427643087006.pdf

Roque, M. (2003). Una concepción educativa para el desarrollo de la cultura ambiental desde una perspectiva cubana. IV Congreso Iberoamericano de Educación Ambiental, Cuba.

Secretaría de Desarrollo Sustentable. (2020a). Residuos Sólidos. Portal del Gobierno de Yucatán. Recuperado de https://sds.yucatan.gob.mx/residuos-solidos/index.php

Secretaría de Desarrollo Sustentable. (2020b). Programa Educativo para la Promoción de una Cultura Ambiental como Forma de Vida (Escuelas Sustentables). Portal del Gobierno de Yucatán. Recuperado de https://sds.yucatan.gob.mx/educacion-ambiental/escuelassustentables.php

Secretaría del Medio Ambiente. (2020). Programa de Gestión Integral de los Residuos Sólidos para la Ciudad de México 2016-2020. Recuperado de https://sedema.cdmx.gob.mx/programas/programa/residuos-solidos

Secretaría del Medio Ambiente y Recursos Naturales [SEMARNAT]. (n.d.) Residuos Sólidos Urbanos: la otra cara de la basura. Recuperado de https://www.gob.mx/cms/uploads/attachment/file/39412/RESIDUOS_S OLIDOS_URBANOS-_ENCARTE.pdf

Stern, M., Powell, R \& Hill, D. (2013). Environmental education program evaluation in the new millennium: what do we measure and what have we learned?. Environmental Education Research, 20 (5), 581-611, DOI: $10.1080 / 13504622.2013 .838749$
Vigotsky, L. (1978). Mind in Society. Cambridge, Mass. USA: Harvard University Press.

West, S. (2015). Understanding participant and practitioner outcomes of environmental education. Environmental Education Research. 21(1) 4560. Retrieved from https://www.tandfonline.com/doi/abs/10.1080/13504622.2013.879695

World Bank. (2020). What a waste 2.0: A Global Snapshot of Solid Waste Management to $2050 . \quad$ Retrieved from https://datatopics.worldbank.org/what-awaste/trends_in_solid_waste_management.html\#: :text=Globally $\% 2 \mathrm{C}$ $\% 20$ most $\% 20$ waste $\% 20$ is $\% 20$ currently,with $\% 20$ landfill $\% 20$ gas $\% 20$ coll ection $\% 20$ systems. 